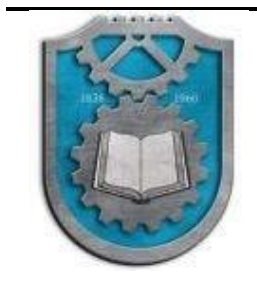

MOBILITY \& VEHICLE

MECHANICS

DOI: $10.24874 / \mathrm{mvm} .2021 .47 .01 .05$

UDC: $629.1 ; 004.45$

\title{
RELIABILITY AND VIABILITY OF THE VEHICLES IN THE CONTEXT OF THE FUTURE TECHNOLOGY - IoT
}

\author{
Marian Florin Mitroi ${ }^{1} *$
}

Received in July 2020

Revised in August 2020

Accepted in September 2020

RESEARCH ARTICLE

\begin{abstract}
The multitude of high performance equipment, as well as modern technologies integrated in the structure of vehicles, have led to an important change in their area of viability. These changes also have effects on maintenance work. Due to sensitivity of the electronic equipment to environmental, temperature and working conditions, it is necessary to adopt effective solutions to protect them and maintain their state of operation. The major challenge among classic vehicles, but also hybrid or electric is the thermal management of this equipments. IoT is a strategic concept for the future of communications between the various functional systems of society, which will adapt and regulate vehicle traffic in relation to the environment. IoT technology will generate certain job opportunities for predictive vehicle maintenance.

The research is a subjective, well-documented analysis, based on which some appropriate measures are proposed for the future, regarding the maintenance process of vehicles. In this direction, the preventive nature of actions and the implementation of 5G / 6G technologies at a global level are pursued. Also, the implementation of hardware and software solutions in the structure of vehicles is considered. They aim to adapt the operation of vehicles to the optimal parameters, by applying preventive corrections.
\end{abstract}

KEY WORDS: reability, viability, IoT

Reliability and viability of the vehicles in the context of the future technology

(C) 2021 Published by University of Kragujevac, Faculty of Engineering

\section{POUZDANOST I ODRŽIVOST VOZILA U KONTEKST BUDUĆE TEHNOLOGIJE - IoT}

${ }^{1}$ Lyubov Sladkoval Moscow, Russia. Russian University of Transport. Moscow, 9 Obraztsova Street, b. 9. 127994, rich.cat2012@yandex.ru *(Corresponding author) 
REZIME: Mnoštvo opreme visokih performansi, kao i moderne tehnologije integrisane u struktura vozila, doveli su do važne promene u njihovom području održivosti. Ove promene takođe imaju uticaja na poslove održavanja. Zbog osetljivosti elektronske opreme na životnu sredinu, temperaturu i radne uslove, neophodno je usvojiti efikasna rešenja za njihovu zaštitu i održavanje njihovog stanja rada. Glavni izazov među klasičnim vozilima, ali takođe i hibridnim ili električnim je termičko upravljanje ovom opremom. IoT je strateški koncept za budućnost komunikacije između različitih funkcionalnih sistema društva, koji će se prilagoditi i regulisati saobraćaj vozila u odnosu na životnu sredinu. IoT tehnologija će stvoriti određene mogućnosti za poslove za prediktivno održavanje vozila.

Istraživanje je subjektivna, dobro dokumentovana analiza, na osnovu koje se predlažu neke odgovarajuće mere za budućnost, a u vezi sa postupkom održavanja vozila. U ovom pravcu preventivna prirodna akcija je primena 5G / 6G tehnologija na globalnom nivou. Takođe, implementacija hardvera i razmatraju se softverska rešenja u strukturi vozila. Cilj im je prilagoditi rad vozila optimalnim parametarima, primenom preventivnih korekcija.

KLJUČNE REČI: izvodljivost, održivost,IoT 


\title{
RELIABILITY AND VIABILITY OF THE VEHICLES IN THE CONTEXT OF THE FUTURE TECHNOLOGY - IOT
}

\author{
Marian Florin Mitroi
}

\section{INTRODUCTION}

Vehicles, regardless of the category to which they belong, have a certain period of operation within the parameters set by the manufacturer. This is determined by a number of factors: the driver's driving style, driving conditions, the environment and temperature in which the journeys are made, the quality of the parts and consumables. Maintaining the state of operation in normal parameters, is a mandatory condition of each owner, both for road safety and for the environment. In the context of the demands generated by ecological mobility, technological developments and also the evolution of data transmissions, various changes are needed so that maintenance processes ensure a high degree of vehicle viability.

Modern 5G / IoT data technologies are making their presence felt more and more in the automotive field, so strategies for raising the viability of vehicles are approached, but also for optimizing the maintenance process.

The paper is a cross-sectional and objective analysis of the road transport system. She highlights current vehicle maintenance methods in the context of future transport technologies and concepts. The proposed solutions are adapted to future eco-mobility conditions.

\section{ECONOMIC CONSIDERATIONS REGARDING THE MAINTENANCE OF VEHICLES}

Maintaining the technical and qualitative performance of vehicles is an imperative requirement established by technical regulations, but also by economic factors. The operation of vehicles without defects, a period as long as possible is directly related to the possibilities of the owner, to maintain or repair them, in case they have failed.

Economically speaking, maintenance processes are associated with the defects that occur. They are influenced by the operating conditions and the quality of the components used in the manufacturing process of the vehicle.

In other words, for the lifetime of the vehicle, until its cassation, there are different periods of operation, which are associated with certain conditions of the vehicle:

- $\quad$ initial - Defects that occur are due to hidden defects in the manufacturing process. They appear from the first requests.

- useful life (maturity) - Defects occur accidentally and can be sudden and / or total. They occur instantly and are generated by overload, which exceeds the permissible strength limits of the components. Not to be confused with those damages, which require periodic replacements due to wear.

- final (aging) - It is short or does not exist at all for many vehicles, because the moral wear that usually occurs before the appearance of this period, take them out of use. It is characterized by the rapid increase in the duration of failures, due to the pronounced wear of the vehicle.

Figure 1 shows the distribution of defects of a vehicle throughout the period of use. 


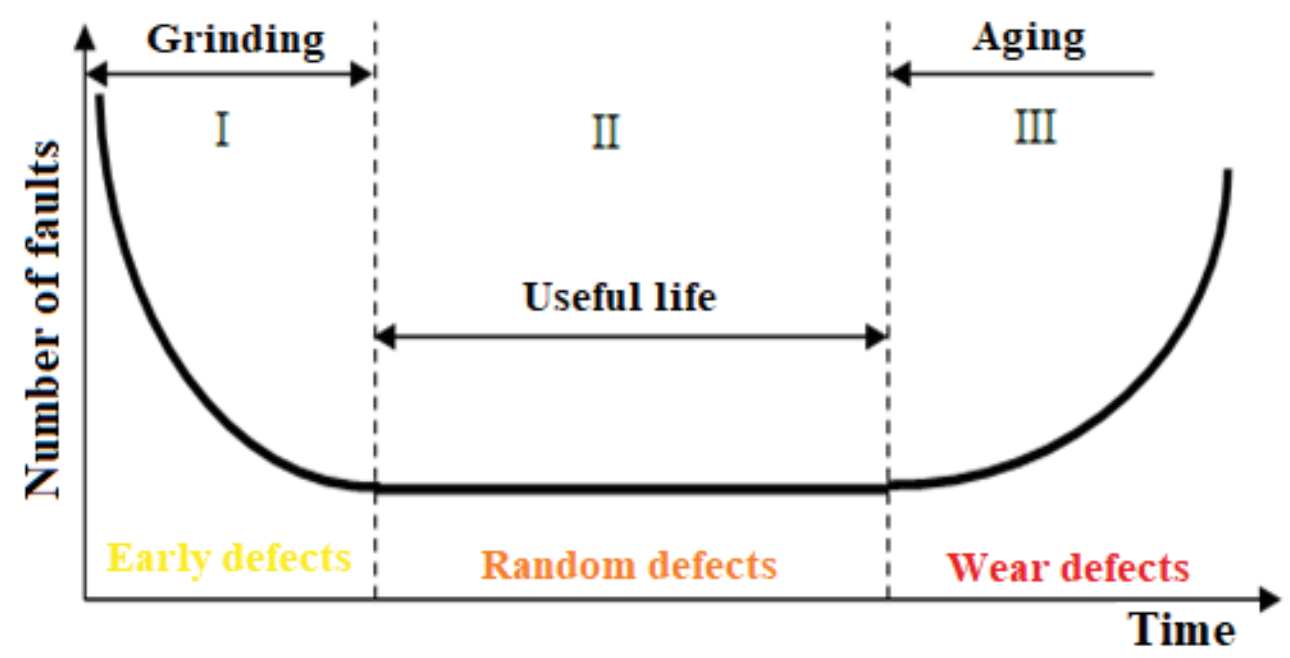

Figure 1 Distribution of vehicle defects in the unit of time

By definition, maintenance is, in general, the totality of operations through which reliability is performed and maintained. Therefore, we can say that, the maintainability of a vehicle during the period of operation is the property of being kept in working order or to be restored, to the state that ensures its normal working parameters.

The maintenance operation must be carried out in accordance with the rules and technical processes prescribed by the manufacturer. The entire maintenance process has implications for maintaining the reliability throughout the life of the vehicle. Taking into account the maintainability indicators of a vehicle, the economic diagram of its reliability can be drawn (Figure 2) [1].

The analysis of the diagram highlights the connection that is created between the different activities and conceptual processes, in order to maintain the safe operating condition of a vehicle. These generate complex action processes, which lead to the restoration of the normal functionality of the vehicle. Maintaining road safety and eco mobility are the main objectives of decision-makers and workers. 


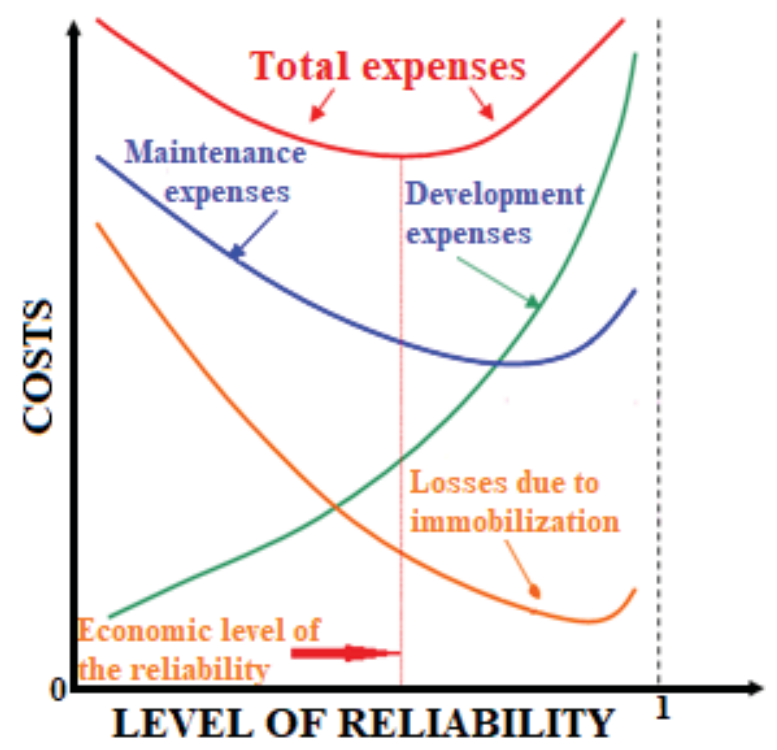

Figure 2 The economic level of reliability of the vehicle

\section{VIABILITY AND RELIABILITY OF MECATRONIC SYSTEMS}

\subsection{Mechatronic Systems of Automobiles}

The mechatronic equipment introduced in the structure of vehicles has become more and more numerous and complex. Currently, the level of development of the sensory capabilities of a mechatronic system is generally determined by the way in which it manages to perform recognition functions similar to those of humans. However, there are two major differences:

- man has multiple possibilities of recognition, being endowed with complex sense organs, which in a mechatronic system are neither necessary nor possible;

- a mechatronic system can be equipped with sensory facilities, which we do not find in humans (example: inductive, capacitive, fluid proximity sensors, or those investigation based on ultrasonic radiation or laser radiation etc).

Mechatronic systems must be able to identify, under certain conditions and limits, the working parameters and react to their changes. The electronic assistance of the steering, braking, suspension systems, as well as of the enginetransmission group are subject to an integrated control (management) concept so that the safety of the occupants and the goods, but also their comfort is at the highest possible level. This implies a permanent exchange of information and the possibility of combining system of conventional functions preestablished with some new ones, realizing a unitary system of management, control and command, called global management (integral). Its optimal operation can be achieved through a compromise between dynamic performance, security, comfort, pollutant emissions and economy of automobile. This compromise is in constantly changing, depending on the current intentions of the driver and the conditions of travel.

The analysis of the reliability of a mechatronic system can be performed at a structural level or at a global level. 
1. At the structural level, when the structure of the system is known, a series of internal variables can be highlighted that determine its state $(\mathrm{X})$.

$$
\dot{X}=f_{(t, u, x)},
$$

The input variables are the demands taken over by the system to perform the function (currents, voltages, pressures), as well as disturbing demands (electromagnetic interference, vibrations, temperatures, humidity). Thus, the output variables are assimilated to the performance of the equipment and its reliability.

2. Globally, the reliability of the system is described by the relationship created between the output vector and the input vector:

$$
Y=A_{(u)},
$$

If the system requirements are deterministic and controllable, the evolution of performance and total reliability are not predictable. Taking into account the structure of a vehicle and the complexity of its mechatronic systems, the analysis of reliability can be performed based on series and mixed. By observing the working method of the mechatronic elements, it can be appreciated that, the analysis of reliability based on mixed layout systems is the most relevant (Figure 3).

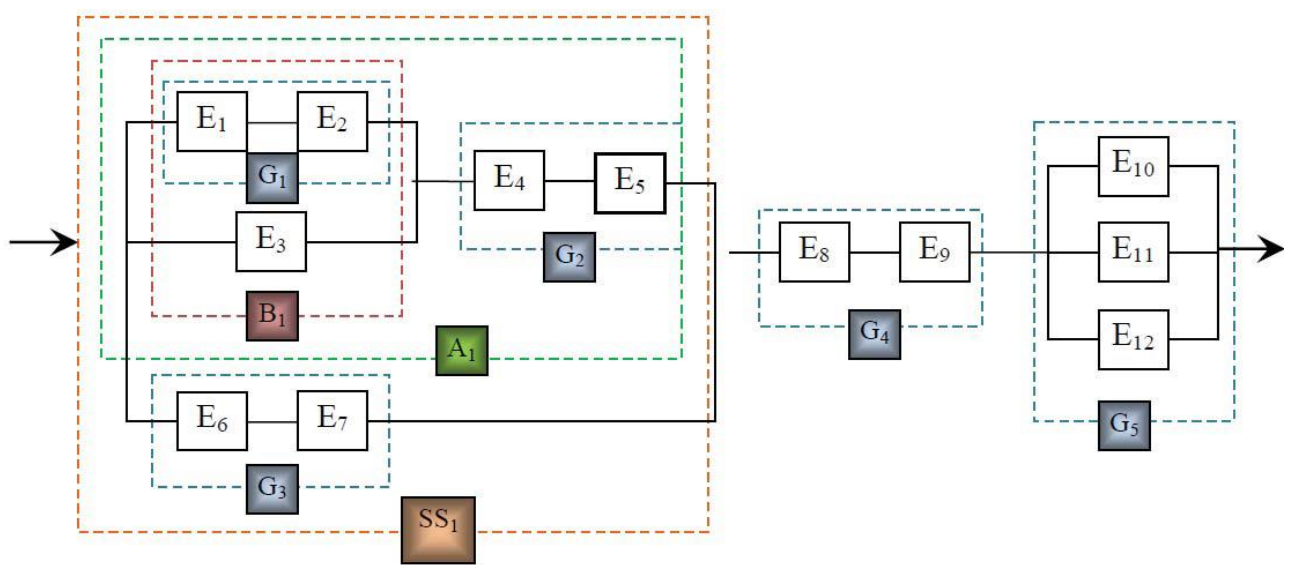

Figure 3 Scheme of vehicle reliability analysis based on the mixed connection of mechatronic equipment

$$
E=\text { equipment } ; G=\text { group of components; } B=\text { control block; } S S=\text { subsystem }
$$

So it is determined by successive components, groups and subassemblies, reaching the establishment of the general level of the system and the vehicle.

\section{2 Viability and Reability of Automobiles}

The increase of the technical level and complexity of the vehicles determined some operating characteristics such as reliability, maintainability, preservability to acquire a major importance, they being followed throughout the life cycle. The reliability of a vehicle is that characteristic that allows its safe use by the owner, for as long as possible, for the intended purpose (for which it was built). A number of concepts associated with reliability are known, such as: 
- probability - is determined based on mathematical methods of statistics and probability, contains values of 0 and 1 ;

- function - involves the satisfaction of a required function (purpose);

- $\quad$ operating conditions - the set of conditions for which it was built (environment and use);

- $\quad$ operating time - involves a period of operation in conditions of maximum safety and security;

- characteristic - determined by the technical working characteristics (power, speed, etc.).

The reliability of vehicles is determined and inseparable from the maintenance process. She can be observed under two aspects: qualitative and quantitative [2]. By analyzing these characteristics, it can be stated that the availability of a vehicle represents its ability to fulfil its constructive purpose, for the established time interval, in terms of reliability and maintainability. So, its availability is higher the higher the reliability, and the lower the maintenance work and the better the quality. By analyzing those presented, as well as Figures 1 and 2, it can be established that, the availability of a vehicle is affected by:

- the probability of functioning without problems in a certain period of time;

- the probability of its failure and the restoration of working capacity, in safe conditions, in some a period oftime.

The availability of a vehicle is obtained by corroborating four characteristics: reliability, maintainability, modernization and conservation (Figure 4).

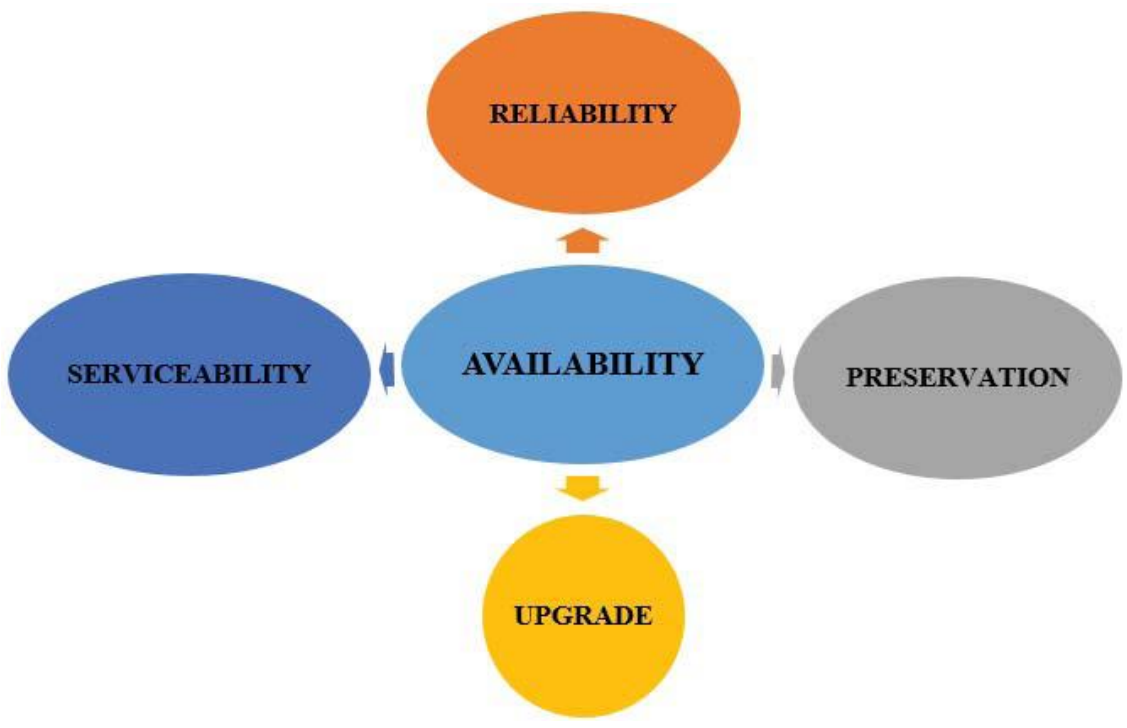

Figure 4 Characteristic elements of the availability and safety in operation of vehicles

The lifetime failure ratio of the vehicle is calculated with the relation:

$$
\lambda_{(\mathrm{t})}=\lambda_{(p)}+\lambda_{(n)}+\lambda_{(c)}
$$


where: $\lambda_{(\mathrm{p})}=$ early failures; $\lambda_{(\mathrm{n})}=$ accidental malfunctions; $\lambda_{(\mathrm{c})}=$ critical failures (period a3a).

The frequency of failures is:

$$
f\left(t_{i}\right)=\frac{k_{i}}{\sum_{i=1}^{n} k_{i}}
$$

where: $\mathrm{i}=$ calculated time interval.

Reliability is calculated with:

$$
R_{(t)}=e^{-\int_{0}^{t} \lambda(t) d t}=e^{-\int_{0}^{t} \lambda\left[\lambda_{(\mathrm{p})}+\lambda_{(\mathrm{m})}+\lambda_{(\mathrm{c})}\right] d t},
$$

\section{THE MAINTENANCE FACTOR IN THE 5G\&IOT CONTEXT MAINTENANCE FACTOR IN THE CONTEXT OF 5G \& IOT}

The 5G communications will amplifying their presence in the technologies implemented on vehicles. Their advantages are undeniable. From safety and comfort, to the environment and mobility, these technologies bring economic and social benefits to citizens, cities and states. Their working possibilities are multiple. They bring major improvements to vehicle safety systems, as well as facilities to road traffic monitoring systems. The multitude of data and information received-analysed and transmitted from sensors to control units and actuators are crucial in the operation of vehicles and the achievement of a safe, fluent and ecological traffic. Essential data is sent to the cloud, processed and retransmitted to various end stations, which ensures a good traffic flow and safe. At the cloud level, flexibility and proper management are needed to be able to manage the flow of data locally, which is related to traffic safety and the operational needs of vehicles. The development of the most automated solutions among the vehicles, determines that the technical infrastructure systems can ensure, filter and manage the essential information from the traffic. The ability of these systems to process different vehicle-specific applications at the same time is crucial, with a multitude of users in parallel (Figure 5). These characteristics require exemplary concordance and lead to a high

The research aims to implement hardware and software solutions, adapted to new technologies, so as to ensure a fast and efficient maintenance process. This is achieved through a unitary and integrated conception of action of the responsible factors, as well as through the efficiency of service activities. Figure 6 shows the scheme of dependence of the process of maintenance of vehicles, on related services.

Vehicles maintenance will permanently require an optimization of solutions for predictability of mechatronic systems operation. She must include sensors and highperformance software, but also adequate connectivity system. Any mechatronic system works based on working parameters. The interconnection of data from various sensors of these systems, can highlight the functional anomalies of the vehicle's equipment (systems). The use of appropriate software can predict the malfunction of a system, or the time left until maintenance operations. 


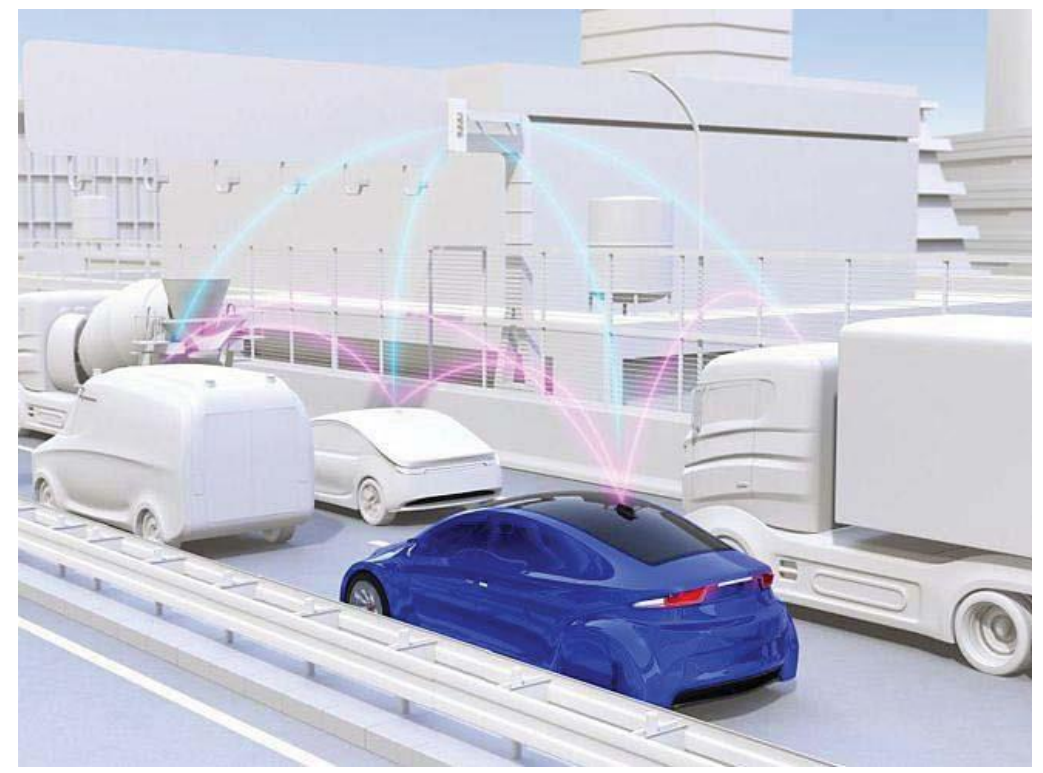

Figure 5 The way of communications in IoT era

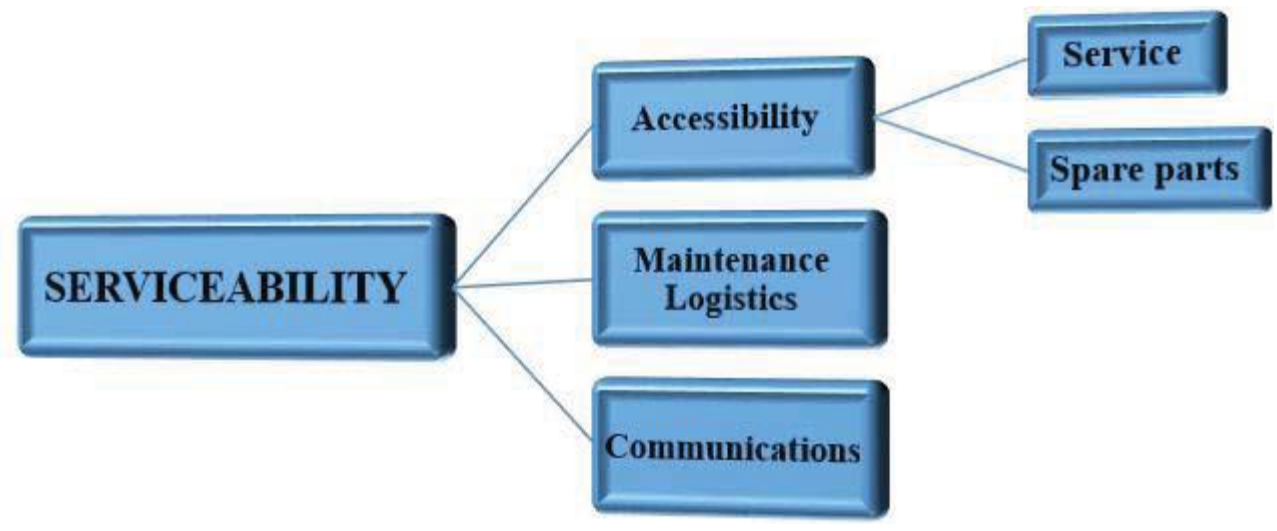

Figure 6 The factors that influencing the maintenance process

The analysis of the presented scheme shows that, the communication system is of major importance. It ensures through the software, the correlation of the information generated by the vehicle with the traffic monitoring and management system and from here with the technical assistance services (Figure 8). The companies specialized in providing maintenance services connected to satellite / cloud, will have at their disposal data regarding the dynamics of the vehicle that requires intervention, as well as data regarding the engine condition parameters and the malfunction situation. Thus, they will know its position, the level of failures, the time and the possibilities of intervention. 


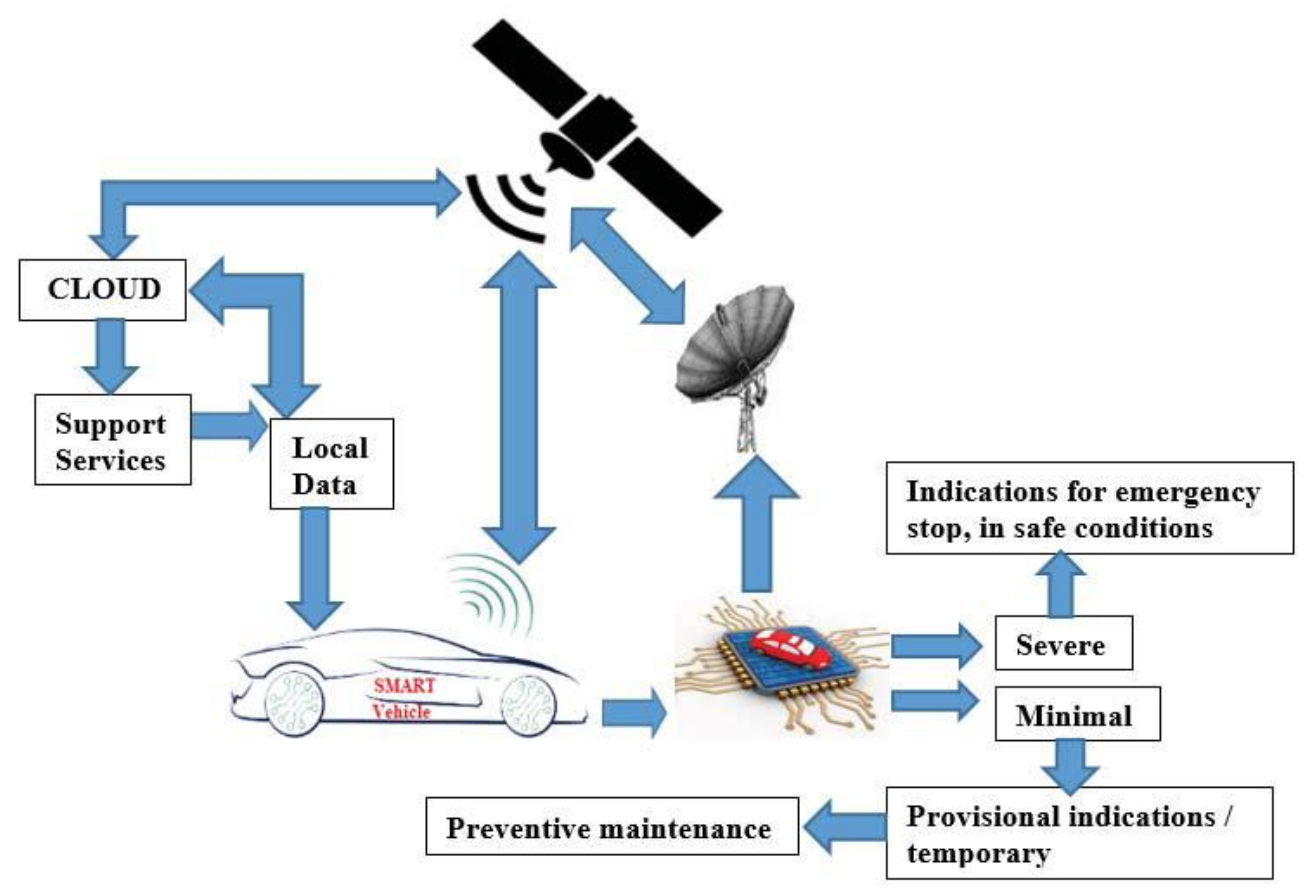

Figure 7 Block diagram with the proposed maintenance strategy for vehicles

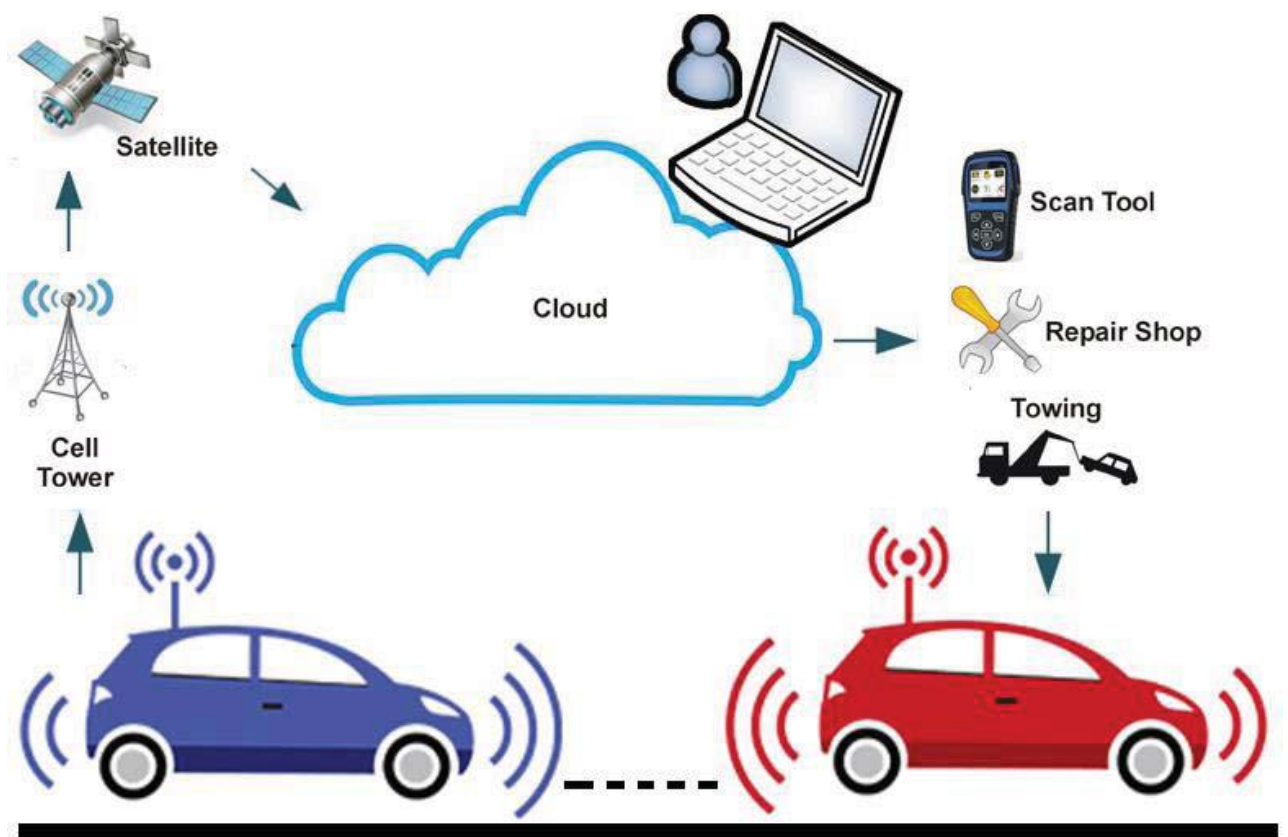

Figure 8 The strategy for maintenance

The information is analyzed and managed according to its importance, and then the answers are transmitted accordingly. Data transmission is performed over short distances $(\mathrm{V} 2 \mathrm{~V}$, V2X), but also over long distances (V2C, V2S) - Figure 9. Therefore, there will be simple 
information processing (data comparisons) as well as complex (integrations, differentiations, mediations, etc.). This will require in high computing power for all systems involved in the traffic process. Progress cannot be achieved without information technology - software.

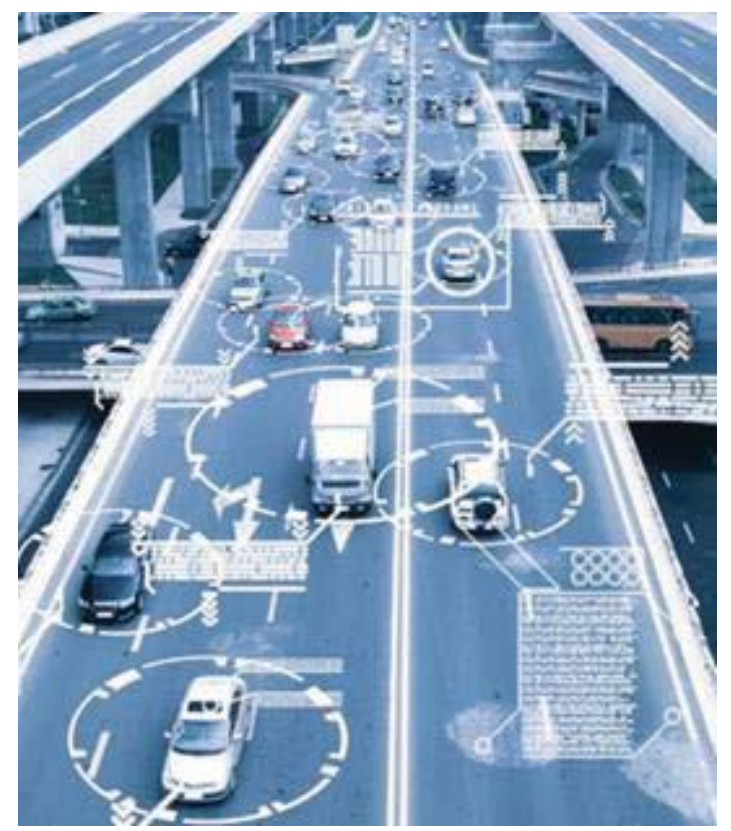

Figure 9 Show how vehicles interact with each other (V2V) and with the environment (V2X)

Considering the fact that, the evolutions in the field of electronics (microprocessors) and computer applications are very fast, we can appreciate that, for mechatronic systems can be developed other applications with / and other performances . Due to these factors, in the not too distant future, vehicles will become integrated structures of digital life.

The mechatronic command and control systems to be implemented will be able to ensure a safe travel with a high level of comfort, for all vehicles. The vehicle displacement management applications such as ADAS, LIDAR require highly developed system architectures, to increase vehicle performance and safety requirements. Also, in the context of IoT and AI, advanced computing solutions are needed, which to raise the level of data processing, improving algorithms and workflows. Thus, in terms of traffic flow and road safety, vehicles will influence each other and collisions between vehicles will no longer exist. The assistance and emergency services will react in a very short time, promptly, with appropriate solutions to the situation created. They will be able to provide real and accurate data on the evolution of the vehicle itself, as well as about the traffic, to integrated monitoring systems and in the cloud. With the implementation of these technologies, the level of road accident prevention, traffic efficiency increases, but also the level of pollution in the cities will also be reduced. As such, predictability solutions will have a major and positive influence on vehicles safety.

Looking ahead, it must be understood the fact that, the strategies adopted for the development of motor vehicles, infrastructure and road traffic need to work perfectly together. The traffic concepts developed must take into account the requirements of climate protection and air quality at city and country level. New directions, such as electro mobility, are also needed. This must be implemented by adopting renewable energy sources (wind, solar). 
The intelligent connection of vehicles with the infrastructure and the service environment is the key to a sustainable and efficient development.

\section{CONCLUSIONS}

Vehicle reliability is a performance feature as well as a marketing parameter.

The modern car is one of the representative mechatronic products and an example of software integration of mechanical, electronic and computer components. Mechatronic equipment for vehicles will largely depend on the performance of the information and communication systems used. The implementation of mechatronics at the highest level aims to increase the operational safety of cars by over $30 \%$ compared to the present, as well as to streamline traffic by more than $25 \%$.

The proposed work strategy, for the transmission of information to and from the vehicle, is a viable approach, but also a starting point for new solutions. The solution aims to streamline the maintenance of vehicles, by identifying a new opportunities to address work actions by service company teams. Vehicle to vehicle and vehicle to infrastructure communication will generate much higher road safety; reduce the number of accidents and road casualties. It will also allow, at the same time, the management and dynamic control of traffic in congested cities, as well as greener transport.

\section{REFERENCES}

[1] Mitroi, M., Arama, C.: On Board Diagnosis Implications on the Viability of Military Patrol and Intervention Vehicles, Publishing House of "Henri Coanda" Air Force Academy, 2014, Brasov, Vol.1, p. 199.

[2] Panaite, V., Popescu, M.O.: Product quality and reliability, MatrixRom Publishing House, 2003, Bucharest, p.. 